\title{
PENGARUH PEMBERIAN AIR KUNYIT (CURCUMA DOMESTICA) \\ TERHADAP PROFIL DARAH MERAH (JUMLAH ERITROSIT, HEMOGLOBLIN DAN HEMATOKRIT) PADA AYAM BROILER \\ (Effect Giving Water Of Turmeric (Curcuma Domestica) On Cell Red Blood Profiles \\ (Total Of Erythrocytes, Hemoglobin And Hematocrit) Of Broiler Chickens)
}

\author{
Khoirina Hanifa, Retno Murwani, Isroli
}

\author{
Program Studi S1 Peternakan \\ Laboratorium Fisiologi dan Biokimia, Departemen Peternakan, \\ Fakultas Peternakan dan Pertanian, Universitas Diponegoro \\ Jl. Prof. H. Soedarto, SH, Tembalang, Kota Semarang \\ khoirinahanifa@gmail.com
}

\begin{abstract}
ABSTRAK
Penelitian ini bertujuan untuk mengetahui pengaruh pemberian air kunyit terhadap profil darah merah (jumlah eritrosit, kadar hemoglobin, dan hematoktrit) pada ayam broiler. Materi yang digunakan yaitu 200 ekor ayam broiler (DOC/day old chicks) strain

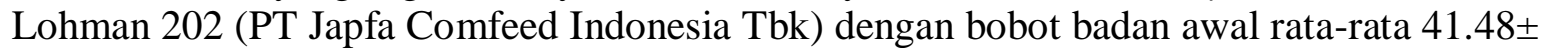
0.99 gram. Pemberian air minum pada minggu pertama dan pada hari ke-11 hingga selesai menggunakan air kunyit. Rebusan air kunyit disiapkan dengan merebus air mineral $600 \mathrm{ml}$ hingga mendidih, kemudian 10 gram kunyit yang telah dicuci bersih dan dimemarkan, dimasukan dalam rebusan air mendidih selama \pm 10 menit. Pemberian air minum dilakukan secara ad libitum. Rancangan percobaan yang digunakan yaitu Rancangan Acak Lengkap (RAL) dengan 5 perlakuan dan 5 ulangan dan setiap unit percobaan terdiri dari 8 ekor ayam Adapun perlakuan yang diberikan yaitu 100\% air minum, 75\% air minum : 25\% air kunyit, 50\% air kunyit : 50\% air minum, 75\% air kunyit : $25 \%$ air minum, dan $100 \%$ air kunyit. Hasil penelitian menujukkan bahwa tidak ada pengaruh pemberian air kunyit terhadap profil darah merah ayam broiler. Simpulan dari penelitian yaitu pemberian air kunyit dalam air minum tidak mengubah profil darah dan tetap berada dalam kisaran normal.
\end{abstract}

Kata Kunci: kunyit, broiler, eritosit, hemoglobin, hematokrit.

\begin{abstract}
The purpose of this research to determine the effect of giving turmeric water to the red blood profile (the amount of erythrocytes, hemoglobin level, and hematoktrit) in broiler chickens. The material used is 200 broiler chickens (DOC / day old chicks) strain Lohman 202 (PT Japfa Comfeed Indonesia Tbk) with an average body weight of $41.48 \pm$ 0.99 gram. Giving of drink water during the first week and on the 11th day to finish using turmeric water. Turmeric boiled water is prepared by boiling mineral water $600 \mathrm{ml}$ to boiling, then 10 grams of turmeric that has been washed and flattened, put in boiling boiling water for \pm 10 minutes. Giving of drink water is ad libitum. The experimental
\end{abstract}


design used was Completely Randomized Design (RAL) with 5 treatments and 5 replications and each experimental unit consisted of 8 chickens. The treatments were $100 \%$ drinking water, $75 \%$ drinking water: $25 \%$ turmeric water, $50 \%$ turmeric water: $50 \%$ drinking water, $75 \%$ turmeric water: $25 \%$ drinking water, and $100 \%$ turmeric water. The results showed that there was no effect of giving turmeric water to broiler broiler blood profile. The conclusion of the research is that the application of turmeric water in drinking water does not change the blood profile and remains within the normal range.

Keywords : Turmeric, broiler, erythrocytes, hemoglobin, hematocrit.

\section{PENDAHULUAN}

Ayam broiler merupakan jenis ayam pedaging unggul yang dikenal dan banyak dikonsumsi oleh masyarakat Indonesia. Ayam broiler memiliki kelebihan pertumbuhannya cepat, tetapi memiliki kelemahan mudah mengalami cekaman dan mudah terserang penyakit akibat virus dan bakteri (Murwani, 2010). Peternak ayam broiler biasanya memberikan pakan komersial karena telah memenuhi standar kebutuhan. Selain itu, pakan komersial mengandung bahan pakan tambahan (imbuhan pakan) berupa antibiotik dan biasanya digunakan oleh para peternak unggas untuk meningkatkan produktivitas (Sinurat dkk., 2009).

Tambahan pakan adalah bahan yang dicampurkan dalam pakan yang dapat mempengaruhi kesehatan maupun nilai gizi pakan. Kunyit merupakan tanaman yang dapat digunakan sebagai tambahan pakan pada ayam broiler. Rimpang kunyit mengandung senyawa aktif berupa kurkuminoid 2,5-6 \% dan minyak atsiri 35\% (Arfah, 2015). Kurkumin memiliki khasiat dapat merangsang dinding kantong empedu untuk mengeluarkan cairan empedu, sehingga nafsu makan meningkat (Muliani, 2015) dan memiliki aktifitas antioksidan yang dapat melindungi hemoglobin dari oksidasi (Fahrurozi dkk., 2013).
Tingginya produktivitas ayam broiler berhubungan erat dengan kondisi hematologisnya, karena darah berperan penting dalam transportasi nutrien maupun sisa metabolisme. Fungsi eritrosit secara umum berperan dalam pertukaran gas dan distribusi oksigen ke dalam sel, yang diperlukan oleh sel untuk proses metabolisme (Yuniwarti, 2012). Oksigen merupakan komponen penting untuk memproduksi ATP, karena ATP merupakan sumber bahan bakar sel untuk energi yang diperlukan sel dalam melakukan metabolism dan efektifitas fungsi tubuh (Isroli dkk., 2009). Proses pembentukan eritrosit baru setiap harinya membutuhkan prekusor untuk mensintesis sel baru antara lain zat besi, vitamin, dan asam amino, dimana proses pembentukan sel tersebut diatur oleh hormon eritroprotein. Oleh karena itu, pemberian air kunyit pada air minum ayam broiler sebagai imbuhan diharapkan dapat mempertahankan atau memperbaiki profil darah broiler yang mudah mengalami stres dan mudah terserang penyakit akibat virus dan bakteri.

Berdasarkan uraian diatas, maka dilakukan penelitian yang bertujuan untuk mengetahui pengaruh pemberian air kunyit terhadap profil darah merah (jumlah eritrosit, hemoglobin, dan hematokrit) pada ayam broiler. Manfaat dari hasil penelitian ini diharapkan dapat bermanfaat bagi khasanah ilmiah dan menambah informasi tentang kegunaan air kunyit sebagai 
imbuhan yang dapat dijadikan aditif alami pengganti antibiotika.

Hipotesis penelitian adalah pemberian air kunyit pada minum dapat mempertahankan dalam kondisi normal atau memperbaiki kondisi profil darah merah (jumlah eritrosit, hemoglobin, dan hematokrit) pada ayam broiler.

\section{MATERI DAN METODE}

\section{Materi}

Penelitian dilaksanakan pada 25 Oktober 2016 sampai 25 November 2016 di Fakultas Peternakan dan Pertanian, Universitas Diponegoro, Semarang. Analisis jumlah eritrosit, kadar hemogloblin dan hematokrit pada ayam broiler dilakukan di Laboratorium Kesehatan Hewan Type B Purwokerto. Bahan yang digunakan yaitu 200 ekor ayam broiler (DOC/day old chicks) strain Lohman 202 yang berasal dari PT Japfa Comfeed Indonesia Tbk

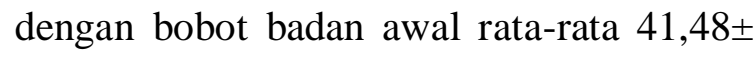
0,99 gram, kandang, air mineral, kunyit, pakan komersial, alkhohol, desinfektan, sekam, vaksin. Alat yang digunakan yaitu thermometer, hygrometer, peralatan pakan dan minum, timbangan pakan dan bobot badan, instalasi listrik, sekat kandang, dan peralatan pengambilan darah yang digunakan diantaranya spuit (disposable syringe), tabung EDTA, coolbox, kapas, kertas label, alat tulis.

\section{Metode}

Kandang penelitian disiapkan dengan sistem litter yang beralas sekam padi dan telah difumigasi. Kandang terdiri dari 25 petak yang setiap petaknya berukuran $60 \mathrm{x}$ $90 \times 60 \mathrm{~cm}$ dan terdiri dari 8 ekor setiap unit kandang. Setiap petak dilengkapi dengan satu tempat pakan dan satu tempat air minum nipple serta lampu pijar sebagai pemanas buatan. Pemeliharaan ayam broiler dilakukan selama 35 hari.

Pemberian air minum pada minggu pertama dan pada hari ke-11 hingga selesai menggunakan air kunyit. Pembuatan air kunyit yaitu merebus air mineral $600 \mathrm{ml}$ hingga mendidih, kemudian 10 gram kunyit dicuci bersih dan dimemarkan, dimasukan dalam rebusan air mendidih selama \pm 10 menit. Setelah rebusan air kunyit mendidih, disaring dalam ember dan didiamkan hingga sesuai dengan suhu ruang, kemudian setelah itu siap diberikan ternak sesuai dengan perlakuan. Pemberian air minum dilakukan secara ad libitum.

Pakan yang digunakan pada penelitian yaitu pakan komersial dari PT. Charoen Pokphand Indonesia. Pemberian pakan yang digunakan pada periode starter (1-21 hari) B-11S dan periode finisher (2135 minggu) BR-1AJ dengan kandungan nutrisi ransum disajikan pada Tabel 1 . Vaksinasi dilakukan dengan vaksin ND (Newcastle Diseases) pada umur 1 hari, Gumboro A pada umur 7 hari dan Gumboro $B$ pada umur 14 hari.

Tabel 1. Kandungan nutrisi pakan PT. Charoen Pokphand Indonesia

\begin{tabular}{|c|c|c|c|c|c|c|c|}
\hline Periode & $\begin{array}{c}\text { Kadar } \\
\text { Air* }\end{array}$ & $\begin{array}{l}\text { Kadar } \\
\text { Abu* }^{*}\end{array}$ & $\begin{array}{l}\text { Protein } \\
\text { Kasar* }\end{array}$ & $\begin{array}{c}\text { Serat } \\
\text { Kasar* }\end{array}$ & Lemak* & Calsium* & Pospor* \\
\hline Starter & 13 & & 21 & & 5 & 0,9 & 0,6 \\
\hline Finisher & 13 & & $20-$ & & 5 & 1,2 & 1 \\
\hline
\end{tabular}

Sumber : *Hasil Analisis Proksimat Laboratorium IlmumNutrisi Ternak dan Pakan, Universitas Diponegoro, Semarang (2017) 
Penelitian menggunakan Rancangan Acak Lengkap (RAL) dengan 5 perlakuan dan 5 ulangan dan setiap unit percobaan terdiri dari 8 ekor ayam. Adapun perlakuan yang diberikan yaitu $\mathrm{T}_{0}=$ pemberian air minum $100 \%$ air, $\mathrm{T}_{1}=$ pemberian $75 \%$ air minum $: 25 \%$ air kunyit, $\mathrm{T}_{2}=$ pemberian $50 \%$ air kunyit : $50 \%$ air minum, $\mathrm{T}_{3}=$ pemberian $75 \%$ air kunyit : $25 \%$ air minum, dan $\mathrm{T}_{4}=$ pemberian $100 \%$ air kunyit. Pengambilan sempel darah dilakukan pada hari ke 28 dengan pemuasaan ternak selam 6 jam sebelum pengambilan darah. Darah diambil melalui bagian sayap ayam yang telah dibersihkan menggunakan alkohol, kemudian spuit (disposable syringe) disuntikkan pada pembuluh darah vena bracialis (sayap). Darah diambil sebanyak $2 \mathrm{ml}$, kemudian dimasukkan ke dalam tabung yang mengandung antikoagulan
EDTA (Ethylene Diamine Tetraacetic Acid). Tabung dikocok membentuk angka delapan, kemudian disimpan dalam cool box sampai dilakukan analisis. Penentuan jumlah eritrosit menggunakan hemocytometer neubeur, penentuan kadar hemoglobin dilakukan menggunakan metode Sahli, dan penentuan nilai hematokrit dengan metode mikrohematokrit.

\section{HASIL DAN PEMBAHASAN}

Berdasarkan penelitian diperoleh data profil darah merah yang meliputi total eritrosit, hemoglobin, hematokrit pada ayam broiler yang diberi perlakuan dengan pemberian air kunyit seperti disajikan pada Tabel 2.

Tabel 2. Data rataan profil darah merah Ayam Broiler yang diberi perlakuan dengan pemberian air kunyit

\begin{tabular}{lccccc}
\hline \multirow{2}{*}{\multicolumn{1}{c}{ Variabel }} & \multicolumn{5}{c}{ Perlakuan } \\
\cline { 2 - 6 } & $\mathrm{T}^{\mathrm{ns}}$ & $\mathrm{T}^{\mathrm{ns}}$ & $\mathrm{T}^{\mathrm{ns}}$ & $\mathrm{T}^{\mathrm{ns}}$ & $\mathrm{T}^{\mathrm{ns}}$ \\
\hline Jumlah Eritrosit $\left(\times 10^{6} / \mathrm{mm}^{3}\right)$ & $3,3 \pm 0,68$ & $3,2 \pm 0,81$ & $3,2 \pm 0,76$ & $2,9 \pm 0,93$ & $3,0 \pm 1,07$ \\
Kadar Hemoglobin $(\mathrm{g} / \mathrm{dl})$ & $9,0 \pm 0,00$ & $9,3 \pm 1,86$ & $8,6 \pm 0,55$ & $8,9 \pm 0,55$ & $8,9 \pm 1,02$ \\
Nilai Hematokrit $(\%)$ & $29,8 \pm 1,3$ & $28,4 \pm 2,1$ & $29,0 \pm 1,2$ & $29,4 \pm 1,7$ & $28,6 \pm 2,2$ \\
\hline
\end{tabular}

Keterangan : $\mathrm{ns}=$ hasil tidak berpengaruh nyata $(\mathrm{P}>0,05)$

Data rataan hasil pengukuran parameter profil darah merah ayam broiler disajikan pada Tabel 2. Analisis statistik menunjukkan bahwa penambahan air kunyit tidak berpengaruh nyata $(\mathrm{P}>0,05)$ terhadap jumlah eritrosit, kadar hemoglobin, dan nilai hematokrit ayam broiler.

Jumlah eritrosit, kadar hemoglobin, hematokrit ayam broiler pada penelitian ini masing-masing berkisar antara 3,0 - 3,3x $10^{6} / \mathrm{mm}^{3}, 8,6-9,0 \mathrm{~g} / \mathrm{dl}, 28,4-29,8 \%$. Menurut Putriani dan Soma (2012) nilai hematokrit normal pada ayam broiler berkisar 22,0\%-35\% dengan rata-rata
$30,0 \%$, untuk kadar hemoglobin antara 7,0 $\mathrm{gr} / \mathrm{dl}-13,0 \mathrm{gr} / \mathrm{dl}$ dengan rata-rata $9,0 \mathrm{gr} / \mathrm{dl}$, dan untuk total eritrosit berkisar antara 2,5$3,5 \times 10^{6} / \mathrm{mm}^{3}$ dengan rata-rata $3,0 \times$ $10^{6} / \mathrm{mm}^{3}$. Kisaran yang relatif sama juga dilaporkan oleh Sadarman (2013), jumlah eritosit normal pada ayam kisaran eritrosit normal ayam sekitar 2,5-3,2 x $10^{6} / \mathrm{mm}^{3}$, kadar normal hemoglobin ayam kisaran 6,5-9,0 g/dl, dan nilai normal hematokrit ayam kisaran 24,0-43\%. Pemberian air kunyit pada penelitian ini masih tergolong aman. Hal ini karena jumlah eritrosit yang didapat termasuk dalam kisaran batas normal. 
Ayam broiler yang tidak mendapat perlakuan pemberian air kunyit dalam penelitian ini memiliki jumlah eritrosit yang cenderung lebih tinggi. Hal tersebut mengindikasi bahwa pemberian dengan pakan komersial sudah mampu mencukupi kebutuhan nutrien untuk membantu proses erithropoesis. Menurut Ali dkk. (2013) bahwa perbedaan jumlah eritrosit dapat dipengaruhi oleh beberapa faktor diantaranya umur, jenis kelamin, bangsa, temperatur, lingkungan, tingkat produksi, dan sistem pemeliharaan. Zat aktif kurkumin yang berperan membantu proses erithropoesis tidak meningkatkan jumlah eritrosit tersebut. Erithropoesis (proses pembetukan eritrosit) dipacu oleh kebutuhan $\mathrm{O}_{2}$, hormon eritroprotein dan ketersediaan (kecukupan) nutrisi.

Jumlah eritrosit menunjukkan kemampuan darah dalam mengangkut oksigen dan kemampuan ayam broiler menggunakan oksigen untuk melakukan metabolisme nutrien. Jumlah eritrosit setiap perlakuan yang normal dapat dijadikan sebagai salah satu indikator bahwa sistem metabolisme tubuh ayam broiler dalam kondisi yang stabil sehingga eritrosit dapat diproduksi dalam jumlah normal dan nutrisi yang dibutuhkan dalam pembentukan sel darah merah terutama protein dan vitamin sudah mencukupi kebutuhan ayam sehingga kesehatan tubuh ayam optimal. Pemberian air kunyit pada penelitian tidak berpengaruh nyata terhadap jumlah eritrosit yang mengindikasi bahwa faktor keadaan ayam yang normal (sehat) maka efek dari kurkumin tidak tampak. Metabolisme dalam tubuh ayam broiler pada masingmasing perlakuan dengan kondisi yang sama sehingga tidak berdampak pada peningkatan kebutuhan oksigen yang mempengaruhi pembentukan eritrosit (eritropoiesis). Pemberian air kunyit juga tidak menurunkan maupun meningkatkan bobot badan antar perlakuan. Hal tersebut mengindikasi bahwa metabolisme dalam tubuh ternak pada setiap perlakuan dalam kondisi yang sama, sehingga tidak berdampak pada peningkatan kebutuhan oksigen yang merangsang pembentukan eritrosit. Menurut penelitian Kusnadi dan Rahmat (2008) bahwa pengaruh yang tidak nyata dapat dipengaruhi oleh kondisi ayam yang sehat sehingga efek dari kurkumin tidak terlihat dan faktor kurangnya konsentrasi penambahan kunyit pada ransum sehingga zat aktif yang terkandung sedikit.

Hemoglobin merupakan bagian terpenting dari eritrosit, karena mengisi sepertiga dari komponen eritrosit setelah air dan stroma, serta berperan penting untuk kelangsungan hidup karena membawa dan mengantarkan oksigen ke jaringan tubuh. Hemoglobin merupakan senyawa organik kompleks yang terdiri dari empat pigmen porifin merah (heme), dimana setiap pigmen mengandung atom besi ditambah globin yang merupakan protein globular yang terdiri dari empat rantai asam-asam amino (Wientarsih, 2013).

Hemoglobin merupakan petunjuk kecukupan oksigen yang diangkut. Kandungan oksigen dalam darah yang rendah menyebabkan peningkatan produksi hemoglobin dan jumlah eritrosit. Penurunan kadar hemoglobin terjadi karena adanya gangguan eritropoesis terutama kadar besi (Fe) dalam tubuh karena besi merupakan komponen pembentukan molekul heme. Oleh karena itu, apabila terjadi kegagalan pengangkutan besi menuju eritoblas dapat menyebabkan anemia hipokromik yaitu penurunan jumlah eritrosit yang mengandung lebih sedikit hemoglobin yang mengidikasi bahwa ternak dalam kondisi tidak sehat (Ali dkk., 2013) 
\begin{tabular}{llr}
\multicolumn{2}{c}{ Pemberian air kunyit tidak } \\
berpengaruh nyata terhadap kadar \\
hemoglobin disebabkan oleh tidak \\
berpengaruh nyatanya jumlah sel darah
\end{tabular} merah karena hemoglobin merupakan komponen dari eritrosit dan kadar hemoglobin berbanding lurus dengan jumlah sel darah merah. Semakin tinggi jumlah sel darah merah maka akan semakin tinggi pula kadar hemoglobin dalam sel darah merah tersebut. Jumlah eritrosit dan kandungan hemoglobin yang normal menunjukkan bahwa kunyit tidak mengandung zat-zat toksik yang dapat menyebabkan lisisnya sel eritrosit ataupun mengganggu proses pembentukan sel darah merah (Napirah dkk., 2013). Kadar hemoglobin setiap perlakuan yang normal dapat dijadikan sebagai salah satu indikator kecukupan oksigen yang diangkut ke seluruh jaringan tubuh untuk proses metabolisme tubuh.

Hematokrit tidak ada perbedaan antar perlakuan karena hematokrit merupakan suatu persentase sel darah merah dalam 100 $\mathrm{ml}$ darah sehingga hematokrit berhubungan dengan jumlah eritrosit, dimana eritrosit merupakan masa sel terbesar dalam darah. Hematokrit, kadar hemoglobin dan jumlah eritrosit menunjukkan hasil yang tidak berbeda dan berjalan sejajar satu sama lain apabila terjadi perubahan karena merupakan suatu rangkaian yang saling berkaitan (Wahyuni dkk., 2012). Hematokrit merupakan perbandingan total padatan darah dengan volume darah, sehingga berkaitan dengan viskositas/kekentalan darah dalam tubuh. Semakin kental darah menandakan tubuh kekurangan cairan sehingga akan memaksimalkan kinerja jantung menjadi lebih cepat dalam memompa darah. Apabila viskositas/kekentalan darah tinggi, maka semakin sulit molekul dalam darah bergerak yang berakibat gangguan sirkulasi oksigen dalam darah sehingga timbul penyumbatan. Oleh karena itu, hematokrit pada setiap perlakuan berada dalam kisaran normal yang mengindikasi bahwa status kesehatan ternak masih dalam kondisi baik.

\section{KESIMPULAN}

Berdasarkan hasil penelitian dapat disimpulkan bahwa pemberian air kunyit tidak mengubah profil darah ayam broiler yang terdiri dari jumlah eritrosit, kadar hemoglobin, hematokrit dan masih berada dalam kisaran normal.

\section{DAFTAR PUSTAKA}

Ali, A. S., Ismayomati dan D. Indrasari. 2013. Jumlah eritrosit, kadar hemoglobin dan hematokrit pada berbagai jenis itik lokal terhadap penambahan probiotik dalam ransum. Jurnal Ilmiah Peternakan 1(3): 1001-1013.

Erniasih, I dan T. R. Saraswati. 2006. Penambahan limbah padat kunyit pada ransum ayam dan pengaruhnya terhadap status darah dan heparayam. Buletin Anatomi dan Fisiologi. 17 (2) : 1-6.

Fahrurozi, N., S. Tantalo dan P. E. Santosa. 2013. Pengaruh pemberian kunyit dan temulawak melalui air minum terhadap gambaran darah pada broiler. Jurnal Ilmiah Peternakan Terpadu. 2 (1): 39-46.

Isroli, S. Susanti, E. Widiastuti, T. Yudiarti dan Sugiharto. 2009. Observasi beberapa variabel hematologis ayam kedu pada pemeliharaan intensif. Seminar Nasional Kebangkitan Peternakan. Program Magister Ilmu Ternak Pascasarjana Fakultas 
Peternakan Universitas Diponegoro. Hal : 548-557.

Kusnadi, E dan A. Rachmat. 2008. Pengaruh penambahan tepung kunyit (Curcuma domestica val) dalam ransum yang diberi minyak jelantah terhadap performan ayam broiler. Jurnal Ilmu Ternak. 8 (1): 25-30.

Muliani, H. 2015. Effect of turmeric (Curcuma domestica val.) extract on broiler blood cholesterol levels. Jurnal Sains dan Matematika. 23 (4) : 107-111.

Murwani, R. 2010. Broiler Modern. Semarang (ID) : Widya Karya.

Napirah, A., Supadmo, dan Zuprizal. 2013. Pengaruh penambahan tepung kunyit (Curcuma domestica valet) dalam pakan terhadap parameter hematologi darah puyuh (Coturnixcoturnix japonica) pedaging. Buletin Peternakan. 37 (2) : 114119.

Putriani S. dan I. G. Soma. 2012. Nilai hematokrit, kadar hemoglobin, dan total eritrosit ayam pedaging yang diinjeksi kombinasi Tylosin dengan Gentamicin. Indonesia Medicus Veterinus. 1(4) : 492-504.

Sadarman. 2013. Status kesehatan ayam pedaging yang diberi limbah kulit buah naga (Hylocereus undatus) dalam air minum sebagai antioksidan. Jurnal Penelitian Sosial Keagamaan. 16 (1) : 14-19.

Sinurat, A. P., T. Purwadaria, I. A. K. Bintang, P. P. Ketaren, N. Bermawie, M. Raharjo dan M. Rizal. 2009. Pemanfatan kunyit dan temulawak sebagai imbuhan pakan untuk ayam broiler. Jurnal Ilmu Ternak Veteriner. 14 (2) : 90-96.
Wahyuni, N. Y., N. Mayasari dan Abun. 2012. Pengaruh penggunaan ekstrak kulit jengkol (Pithecellobium jiringa (Jack) Prain) dalam ransum terhadap nilai hematologi ayam broiler. Student E-Journal. 1(1) : 15.

Wientarsih I., S. D. Widhyari dan T. Aryanti. 2013. Kombinasi imbuhan herbal kunyit dan zink dalam pakan sebagai alternatif pengobatan kolibasilosis pada ayam pedaging. Jurnal Veteriner. 14 (3) : 327-334.

Yuniwarti, E. Y. W. 2015. Profil darah ayam broiler setelah vaksinasi ai dan pemberian berbagai kadar vco. Buletin Anatomi dan Fisiologi. 23 (1) : 38-46. 